\title{
IDENTIFIKASI KANDUNGAN ASAM FENOLAT DAN AKTIVITAS ANTIOKSIDAN BERAS KETAN MERAH (ORYZA SATIVA VAR. GLUTINOSA)
}

\author{
Identification of Phenolic compounds and Antioxidant Activity of Red Glutinous Rice \\ (Oryza sativa var. glutinosa)
}

\author{
Hera Sisca Prasmita*, Jhauharotul Muchlisyiyah, Tri Dewanti Widyaningsih, \\ Sabrina W. Purbasari \\ Jurusan Teknologi Hasil Pertanian - Fakultas Teknologi Pertanian - Universitas Brawijaya \\ Jl. Veteran, Malang 65145 \\ *Penulis Korespondensi: email: herasisca87@gmail.com
}

\begin{abstract}
ABSTRAK
Beras ketan (Oryza sativa var. glutinosa) yang umum dikenal dan dimanfaatkan masyarakat saat ini adalah beras ketan putih dan beras ketan hitam, sedangkan beras ketan merah sangat jarang diketahui oleh sebagian besar masyarakat. Masyarakat di daerah tertentu seperti di Pakis, kabupaten Pacitan telah lama mengenal, menanam, dan mengolah beras ketan merah menjadi snack seperti tape ketan merah, rengginang ketan merah, dan lain sebagainya. Diduga ketan merah sama seperti beras berpigmen lainnya mengandung asam fenolat dan senyawa bioaktif lainnya serta memiliki aktivitas antioksidan. Penelitian ini bertujuan untuk identifikasi kandungan asam fenolatat pada ketan pecah kulit, ketan sosoh dan bekatulnya. Setiap sampel diekstrak kandungan fenolat bebas, fenolat terikat dan fenolat terkonjugasi kemudian hasil ekstraksi dianalisis total fenolat metode folin-ciocalteau serta aktivitas antioksidan metode DPPH. Penelitian ini bersifat deskriptif kuantitatif, dengan tiga kali ulangan. Pada semua sampel, baik pada ketan pecah kulit, ketan sosoh (bagian endosperm) maupun bekatul (bran) mengandung lebih banyak total fenolat terikat dan terkonjugasi (bebas-terikat) daripada fenolat bebas. Aktivitas antioksidan ekstrak senyawa fenolat tertinggi terdapat pada ketan merah pecah kulit meliputi semua jenis fenolat yaitu ekstrak fenolat bebas $\mathrm{IC}_{50} 4.52 \mathrm{mg} / \mathrm{ml}$, fenolat terkonjugasi $3 \mathrm{IC}_{50} 9.92 \mathrm{mg} / \mathrm{ml}$, dan fenolat terikat $\mathrm{IC}_{50} 30.65 \mathrm{mg} / \mathrm{ml}$
\end{abstract}

Kata kunci : Antioksidan, Asam Fenolat, Beras Ketan Merah, Deskriptif Kualitatif

\section{ABSTRACT}

The most common Glutinous rice (Oryza sativa var. glutinosa) is white glutinous rice and black glutinous rice, but red glutinous rice rather infrequently. However, only few people have known about red glutinous rice, local glutinous cultivars in Pakis, Pacitan, East Java. People in there are used to cultivating red glutinous rice for long time ago and processing into various kinds of snack, such as tape, rengginang. Like the other pigmented rice, red glutinous rice contained phenolic and other bioactive compounds which contained antioxidant activity. This study investigated the phenolic compounds of unpolished red glutinous rice, polished red glutinous rice and bran red glutinous rice. Free phenolic compounds was extracted from each samples, as well as the bound-free phenolic and bound phenolic, then analyzed total phenolic and antioxidant activity by using DPPH method. This research was quantitative descriptive with triplicate measurements. The total phenolic content (TPC) of both bound phenolic acids extract and free/conjugated phenolic acids extract were higher than free phenolic acids extract in all samples, including unpolished red glutinous rice, polished red glutinous rice and bran red glutinous rice. Antioxidant capacity of all kinds of phenolic acids extract was highest in unpolished red glutinous rice, that is free phenolic acids extract $I_{50}$ $4.52 \mathrm{mg} / \mathrm{ml}$, free/conjugated phenolic acids extract $3 I_{50} 9.92 \mathrm{mg} / \mathrm{ml}$ and bound phenolic acids extract $I_{50}$ $30.65 \mathrm{mg} / \mathrm{ml}$

Keywords: Antioxidant, Descriptive Qualitative, Phenolic Acid, Red Glutinous rice 


\section{PENDAHULUAN}

Beras ketan (Oryza sativa var.glutinosa) adalah jenis beras yang tumbuh di Asia Tenggara dan Asia Timur. Beras ketan di Indonesia merupakan salah satu bahan pangan penting yang digunakan dalam pembuatan aneka olahan makanan seperti lemper, tape, bubur ketan, dodol, brem, dan rengginang (Ernayanti, 2003; Rasyid, 2004; Sukenti et al., 2016). Pemanfaatan beras ketan dalam makanan pada umumnya dalam bentuk tepung, dalam bentuk pecah kulit dan ketan sosoh. Beras ketan memiliki perbedaan warna diantaranya putih, hitam, dan merah (Suhartatik et al., 2013; Balai Besar Penelitian Tanaman Padi, 2015; Rohaeni dan Hastini, 2015; Sattaka et al., 2017).

Beras ketan merah tergolong varietas ketan lokal daerah tertentu yang relatif langka. Masyarakat di daerah Pakis, kabupaten Pacitan telah lama menanam dan mengolah beras ketan merah menjadi berbagai olahan makanan dimana beras ketan merah ini diduga juga berpotensi seperti halnya beras ketan hitam yaitu sebagai sumber karbohidrat, antioksidan, senyawa bioaktif dan serat yang penting bagi kesehatan (Kadirantau, 2000; Sompong et al., 2011; Suhartatik et al., 2013; Badan Perencanaan Pembangunan Daerah Pemerintah Provinsi Jawa Timur, 2015; Muchlisyiyah et al., 2016).

Adapun pada beras ketan umumnya mengandung asam fenolat, flavonoid, antosianin dan $\gamma$ oryzanol (Gunaratne et al., 2013; Pereira-Caro et al., 2013; Phonsakhan dan Kong-Ngern, 2015; María et al., 2016). Pada beras, asam fenolat terdapat pada lapisan aleuron (bran) dalam berbagai bentuk, diantaranya asam fenolat larut air dan asam fenolat tidak larut air. Asam fenolat larut air terdiri dari asam fenolat bebas (aglikon) dan asam fenolat terkonjugasi (sebagai ester, glikosida). Pada asam fenolat tidak larut air, asam fenolat terikat kovalen pada polimer dinding sel seperti selulosa, hemiselulosa (arabinoxilan), lignin, pektin (Luo et al., 2013).

Asam fenolat bebas dapat diekstrak dengan larutan solvolisis seperti air, methanol, etanol, dan aseton. Metanol 80\% merupakan pelarut yang paling sering digunakan untuk mengekstrak fenolat bebas dari sampel beras. Fenolat terikat pada umumnya dapat diekstrak dengan basa kuat dari residu hasil ekstraksi asam fenolat bebas (Alves et al., 2016).
Beras berpigmen memiliki kandungan komponen fenolat yang tinggi, sementara pada beras yang disosoh berkali-kali semakin sedikit (Paiva et al., 2014; Walter et al., 2013). Komponen asam fenolat terbukti berpotensi sebagai antioksidan, anti-inflamasi, antikarsinogenik (Kaliora et al., 2014; Ling et al., 2001; Liu, 2007; Yawadio et al., 2007; Shao dan Bao, 2015).

Berdasarkan hasil penelitian Zaupa et al. (2015) dan Zhang et al. (2015), komponen fenolat yang terkandung baik pada beras berpigmen maupun tidak, diantaranya adalah asam protokatekin, asam sinapsat, asam vanilat, asam p-kaumarat, dan asam ferulat. Mengingat begitu besar potensi senyawa bioaktif ketan merah dan belum banyak penelitian mengenai karakteristik senyawa fenolik yang terkandung dalam ketan merah. Oleh karena itu, penelitian ini bertujuan untuk identifikasi senyawa fenolat serta aktivitas antioksidan ketan merah pecah kulit, ketan sosoh, dan bekatul ketan merah.

\section{BAHAN DAN METODE}

\section{Bahan}

Bahan yang digunakan dalam penelitian ini adalah gabah ketan merah yang didapatkan dari desa Pakis, kabupaten Pacitan, Jawa Timur. Gabah ketan merah kemudian disosoh sebanyak satu kali, sehingga didapatkan bulir utuh (pecah kulit). Penyosohan kedua dilakukan untuk mendapatkan endosperm (ketan sosoh), serta diperoleh sisa penyosohan yaitu bekatul. Bahan kimia yang digunakan HCL $1 \mathrm{M}, \mathrm{HCL} 4 \mathrm{M}$, metanol $80 \%$, metanol $50 \%$, air, akuades, $n$-hexane, etil asetat, $\mathrm{NaOH} 4 \mathrm{M}$, sodium karbonat, Buffer $\mathrm{pH}$ 1 teknis, Buffer $\mathrm{pH}$ 4,5 teknis, reagen FolinCiocalteu 10\%, standar asam galat, DPPH, standar asam askorbat.

\section{Alat \\ Alat yang digunakan dalam penelitian ini adalah tabung reaksi, erlenmeyer $250 \mathrm{ml}$ dan $100 \mathrm{ml}$, spatula kaca, spatula besi, corong gelas, corong pemisah $100 \mathrm{ml}$, gelas ukur 50 $\mathrm{ml}$ dan $100 \mathrm{ml}$, beaker glass $50 \mathrm{ml}$ dan $500 \mathrm{ml}$, labu ukur $10 \mathrm{ml}$, pipet tetes, pipet volume 1 $\mathrm{ml}$ dan $10 \mathrm{ml}$, bola hisap, mortar, rak tabung reaksi, botol kaca berwarna gelap, alumu-}


nium foil, kertas saring kasar, kertas saring halus, blender Philips, ayakan 80 mesh, $\mathrm{pH}$ meter Rex model pHs-3C, centrifuge (Hettich zentrifugen), spektrofotometer UV-VIS, kuvet, tube, timbangan analitik (Denver instrument M310), vortex, rotary vacuum evaporator (IKA RV 10 digital), sentrifugasi dingin (Tony MX-305), shaker (Unimax 2010 Heidolph.

\section{Metode}

Penelitian ini bersifat deskriptif kuantitatif dan dilakukan dalam dua tahap. Tahap pertama adalah persiapan sampel untuk mendapatkan tepung ketan merah pecah kulit, tepung bekatul, dan tepung ketan merah sosoh. Tahap kedua adalah ekstraksi kandungan senyawa bioaktif fenolat bebas, fenolat terkonjugasi, fenolat terikat. Selanjutnya hasil ekstraksi fenolat dianalisis total fenolat dan diukur aktifitas antikosidannya metode DPPH.

\section{Ekstraksi Fenolat Bebas}

Senyawa fenolat bebas diekstraksi menggunakan metode folin-ciocalteau (Qiu et al., 2010). Sampel tepung ketan merah ditimbang sebanyak 5 g, diekstraksi sebanyak dua kali dengan pelarut metanol $80 \%$ sebanyak $100 \mathrm{ml}$. Selanjutnya, campuran digoyangkan secara kontinyu menggunakan shaker selama 30 menit dalam suhu ruang. Sampel yang telah tercampur selanjutnya dipisahkan supernatannya menggunakan sentrifuge selama 10 menit pada suhu 4 ${ }^{\circ} \mathrm{C}$. Supernatan selanjutnya dikumpulkan dan digabungkan, kemudian diatur $\mathrm{pH}$ sampel sebesar 1.5-2.0, menggunakan HCL $1 \mathrm{M}$. Tahapan selanjutnya adalah pemekatan menggunakan rotary vacuum evaporator pada suhu $40{ }^{\circ} \mathrm{C}(80 \mathrm{rpm}, 100 \mathrm{mBar})$. Selanjutnya dilakukan penghilangan fraksi nonpolar menggunakan pelarut n-hexane sebanyak $10 \mathrm{ml}$. Tahapan lanjutannya adalah proses ekstraksi menggunakan etil asetat $45 \mathrm{ml}$ sebanyak tiga kali. Sampel ekstraksi pertama hingga ketiga digabungkan untuk kemudian dipekatkan dengan rotary vacuum evaporator pada suhu $40^{\circ} \mathrm{C}$ (80 rpm, $\left.100 \mathrm{mBar}\right)$. Ekstrak kemudian dilarutkan dengan pelarut metanol 50\% sebanyak $5 \mathrm{ml}$ dan digunakan sebagai ekstrak kasar fenolat bebas.

\section{Ekstraksi Fenolat Terkonjugasi}

Senyawa fenolat bebas terikat di ekstraksi menggunakan metode yang dimodifikasi dari Li et al. (2008). Sampel tepung ketan merah ditimbang sebanyak $5 \mathrm{~g}$, diekstraksi sebanyak dua kali dengan pelarut metanol $80 \%$ sebanyak $100 \mathrm{ml}$, dengan perbandingan berat sampel dan volume pelarut 1:20. Setelah didapatkan konsentrat supernatan, selanjutnya ditambahkan $40 \mathrm{ml} \mathrm{NaOH} 4 \mathrm{M}$ untuk menghidrolisis sampel selama 1 jam di bawah gas nitrogen. Selanjutnya campuran diatur $\mathrm{pH}$ antara 1.52.0 menggunakan $\mathrm{HCl}$. Larutan selanjutnya dipisahkan dari senyawa nonpolar menggunakan pelarut n-hexane sebanyak $10 \mathrm{ml}$. Selanjutnya, dilakukan ekstraksi menggunakan etil asetat $45 \mathrm{ml}$ sebanyak tiga kali. Sampel ekstraksi pertama hingga ketiga digabungkan selanjutnya dipekatkan dengan rotary vacuum evaporator pada suhu $40{ }^{\circ} \mathrm{C}(80$ rpm, 100 mBar). Ekstrak kering dilarutkan dengan pelarut metanol $50 \%$ sebanyak $5 \mathrm{ml}$ dan digunakan sebagai ekstrak kasar fenolat bebas terikat. Residu ekstrak selanjutnya diukur kandungan total fenolat (TPC) dengan metode Folin-Ciocalteau.

\section{Ekstraksi Fenolat Terikat}

Residu dari ekstraksi fenolat bebas terikat dicuci menggunakan akuades untuk selanjutnya digunakan dalam ekstraksi senyawa fenolat terikat (Zhang et al., 2010). Residu ditimbang berat awalnya, dihidrolisis dengan $5 \mathrm{ml} \mathrm{NaOH} 4 \mathrm{M}$ pada temperatur ruang selama satu jam dan di hidrolisis di bawah gas nitrogen. Setelah proses digesti selesai, campuran diatur $\mathrm{pH}$ antara 1.5-2.0 menggunakan $\mathrm{HCl}$, kemudian dilakukan sentrifugasi dengan kecepatan $10000 \mathrm{rpm}$ selama 10 menit. Supernatan ditambahkan pelarut n-hexane sebanyak $10 \mathrm{ml}$, kemudian dipisahkan dari fraksi nonpolar menggunakan corong pemisah. Selanjutnya dilakukan ekstraksi dengan etil asetat sebanyak $10 \mathrm{ml}$ sebanyak tiga kali. Sampel ekstraksi pertama hingga ketiga digabungkan selanjutnya dipekatkan dengan rotary vacuum evaporator pada suhu $40^{\circ} \mathrm{C}(80$ rpm, 100 mBar). Ekstrak kering dilarutkan dengan pelarut metanol $50 \%$ sebanyak $5 \mathrm{ml}$ dan digunakan sebagai ekstrak kasar fenolat terikat.

\section{Penentuan Total Fenolat}

Penentuan total senyawa fenolat dengan metode Folin-Ciocalteu (Shen et al., 2009) menggunakan asam galat sebagai standar. Ekstrak sampel sebanyak $0.01 \mathrm{~g}$ 
ditambahkan metanol $0.5 \mathrm{ml}$, akuades $2.5 \mathrm{ml}$, dan larutan Folin-ciocalteau $0.1 \mathrm{ml}$, kemudian divortex dengan kecepatan $10000 \mathrm{rpm}$ selama 3 menit. Pada larutan ditambahkan $1 \mathrm{ml} \mathrm{Na} \mathrm{CO}_{3}$ (75 gr/l), diinkubasi selama 30 menit dalam kondisi gelap pada suhu ruang, absorbansi ditera menggunakan spektrofotometer dengan panjang gelombang $764 \mathrm{~nm}$. Asam galat digunakan sebagai standar dan kurva kalibrasi dibuat dengan asam galat konsentrasi $0,10,20,30$, $40 \mathrm{ppm}$.

\section{Penentuan Aktivitas Antioksidan Metode DPPH}

Kapasitas penangkapan radikal bebas DPPH ditentukan dengan metode yang dimodifikasi dari Sharma dan Bhat (2009). Sebanyak $100 \mathrm{mg}$ sampel dimasukkan ke dalam labu ukur $25 \mathrm{ml}$, kemudian ditambahkan pelarut metanol $80 \%$. Selanjutnya dibuat seri pengenceran larutan ekstrak, kemudian sebanyak $1 \mathrm{ml}$ sampel masing-masing konsentrasi diambil dan dimasukkan tabung reaksi. Proses selanjutnya ditambahkan DPPH $0.2 \mathrm{mM}$ sebanyak $1 \mathrm{ml}$. Sampel di inkubasi selama 30 menit pada suhu ruang dan kondisi gelap. Pengukuran absorbansi dilakukan dengan menggunakan spektrofotometer $\lambda 517 \mathrm{~nm}$, dan sampel diukur secara duplo.

\section{Analisis Data}

Data-data yang telah diperoleh pada saat melakukan penelitian diolah menggunakan metode analisis deskriptif kuantitatif, yaitu dengan membandingkan menggunakan literatur yang telah ada untuk dapat disimpulkan hasil penelitian tersebut. Pembuktian dilakukan menggunakan ANOVA single factor dengan selang kepercayaan $\mathrm{p}<0.05$, jika terjadi beda nyata kemudian dilakukan Uji BNT.

\section{HASIL DAN PEMBAHASAN}

\section{Rendemen Hasil Ekstraksi Senyawa Fenolat}

Senyawa fenolat yang terkandung dalam gabah beras ketan terbagi menjadi dua, yaitu senyawa mudah larut dan tidak larut. Senyawa mudah larut merupakan senyawa fenolat bebas dan terkonjugasi, sedangkan senyawa tidak terlarut, atau senyawa fenolat terikat yang strukturnya teresterifika- si pada dinding sel (Wang et al., 2015; Chen et al., 2017). Pada Gambar 1 ditunjukkan rendemen fenolat bebas tertinggi diperoleh dari ekstraksi ketan pecah kulit, yaitu $10.76 \%$, rendemen fenolat terkonjugasi (bebas-terikat) tertinggi diperoleh dari ekstrasi bekatul, yaitu $11.36 \%$. Namun pada rendemen fenolat terikat yang terekstrak dari ketiga sampel hanya sedikit.

\section{Kadar Total Fenolat Beras Ketan Merah}

Pengukuran kadar total fenolat beras ketan merah metode Folin-ciocalteau dilakukan pada sampel ekstrak fenolat bebas, terkonjugasi dan terikat. Kandungan total fenolat beras ketan merah disajikan pada Tabel 1. Pada Tabel 1 terlihat bahwa kandungan total fenolat pada ekstrak fenolat bebas tertinggi didapatkan pada bekatul 28.75 mg GAE/g, dan total fenolat pada ekstrak fenolat terkonjugasi tertinggi terdapat pada ketan pecah kulit $58.07 \mathrm{mg}$ GAE/g. Total fenolat ekstrak fenolat terikat tertinggi terdapat pada bekatul $90.37 \mathrm{mg}$ GAE/g. Tabel 1 juga menunjukkan bahwa pada semua sampel, baik pada ketan pecah kulit, ketan sosoh (bagian endosperm) maupun bekatul (bran) mengandung lebih banyak total fenolat terikat dan terkonjugasi daripada fenolat bebas, meskipun rendemen fenolat terikat yang diperoleh pada saat ekstraksi dari semua jenis sampel relatif sedikit. Hal ini sejalan dengan penelitian Shao dan Bao (2014) pada sampel beras putih, merah, dan hitam, ditemukan bahwa total fenolik terikat dan terkonjugasi secara signifikan lebih tinggi dibandingkan total fenolik bebas yang terkandung pada biji utuh, embrio, dan bran bekatul masing-masing jenis beras tersebut.

Menurut Shao dan Bao (2014) komponen fenolat terikat yang terdeteksi menggunakan metode HPLC LC-MS/MS, diantaranya adalah ferulat, $p$-coumaric, syringic, dan asam isoferulat terkandung dalam beras putih, beras merah, dan beras hitam. Kemungkinan komponen fenolat terikat tersebut juga terkandung di dalam ketan merah.

Tabel 1 juga menunjukkan bahwa bekatul relatif tinggi total fenolatnya untuk semua jenis fenolat yaitu fenolat bebas 28.75 mg GAE/g, terkonjugasi $51.12 \mathrm{mg}$ GAE/g dan fenolat terikat $90.37 \mathrm{mg}$ GAE/g, dibandingkan ketan sosoh dan ketan pecah kulit. Hal ini dikarenakan senyawa fenolat pada beras ketan terakumulasi pada perikarp dan testa atau bran kernel (bekatul) beras hasil 


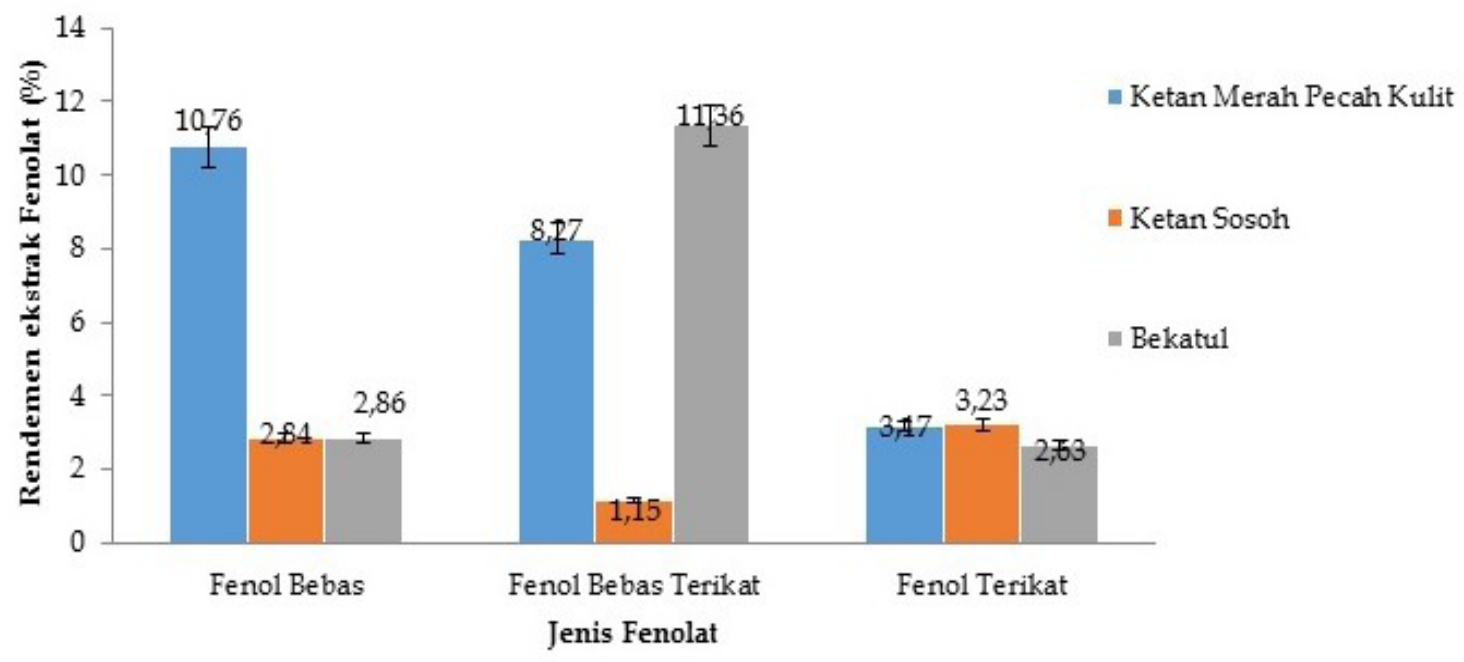

Gambar 1. Rendemen ekstrak senyawa fenolat pada beras ketan merah

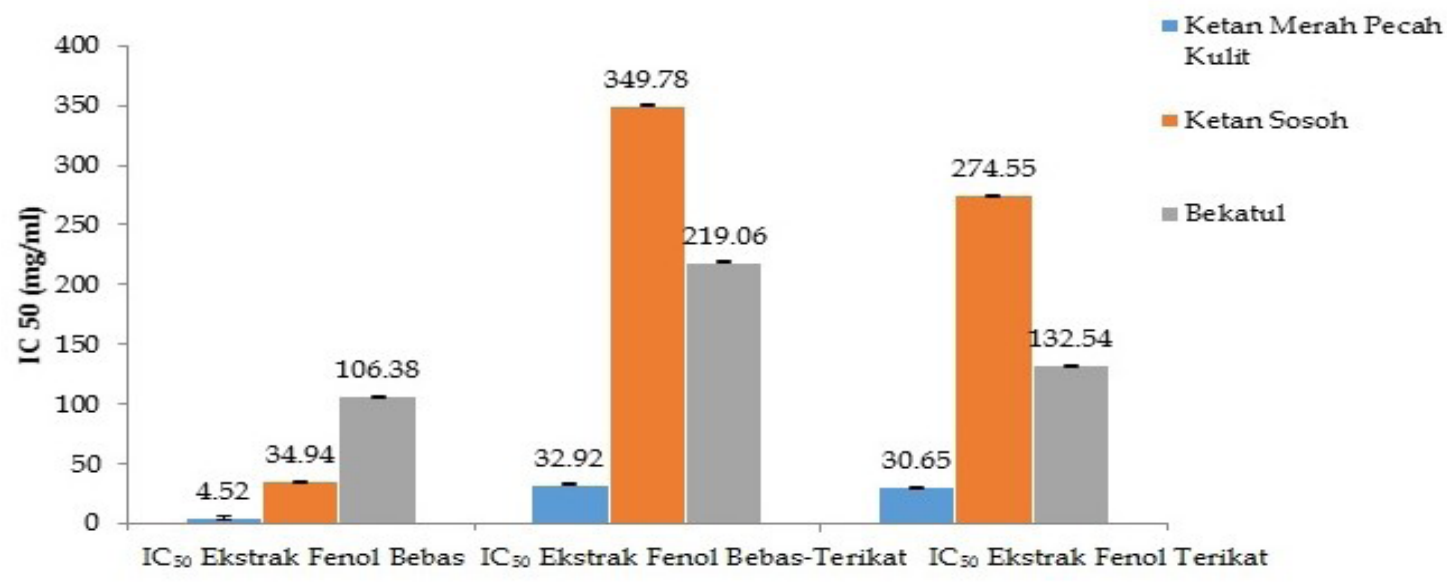

Jenis Fenolat

Gambar 2. $\mathrm{IC}_{50}$ ekstrak senyawa fenolat beras ketan merah

Tabel 1. Total fenolat beras ketan merah

\begin{tabular}{|c|c|c|}
\hline \multicolumn{2}{|c|}{ Sampel } & $\begin{array}{l}\text { Total Fenolat } \\
\text { (mg GAE/g) }\end{array}$ \\
\hline \multirow{3}{*}{ Ekstrak Fenolat Bebas } & Pecah Kulit & $23.37 \pm 6.51^{b}$ \\
\hline & Ketan Sosoh & $10.62 \pm 1.11^{\mathrm{a}}$ \\
\hline & Bekatul & $28.75 \pm 2.46^{b}$ \\
\hline \multirow{3}{*}{$\begin{array}{l}\text { Ekstrak Fenolat Bebas-Terikat } \\
\text { (terkonjugasi) }\end{array}$} & Pecah Kulit & $58.07 \pm 2.19^{c}$ \\
\hline & Ketan Sosoh & $41.87 \pm 1.44^{\mathrm{a}}$ \\
\hline & Bekatul & $51.12 \pm 2.44^{\mathrm{b}}$ \\
\hline \multirow{3}{*}{ Ekstrak Fenolat Terikat } & Pecah Kulit & $89.04 \pm 6.64^{b}$ \\
\hline & Ketan Sosoh & $48.62 \pm 4.35^{a}$ \\
\hline & Bekatul & $90.37 \pm 1.20 b$ \\
\hline
\end{tabular}


samping penggilingan gabah (Gunaratne et al., 2013). Menurut Muntana dan Prasong (2010), perikarp serta testa pada bekatul beras akan mengakumulasi semua senyawa fitokimia yang ada.

\section{Aktivitas Antioksidan Ekstrak Senyawa Fenolat}

Senyawa fenolat terkonjugasi merupakan senyawa fenolat yang strukturnya teresterifikasi pada gugus gula atau komponen molekul lainnya (Wang et al., 2015). Berbeda dengan fenolat terkonjugasi, senyawa fenolat terikat merupakan senyawa fenolat yang tidak mudah larut dalams pelarut seperti metanol, etanol, dan aseton tanpa bantuan hidrolisis alkali. Senyawa fenolat terikat pada struktur komponen dinding sel seperti selulosa, hemiselulosa, lignin, pektin, dan protein (Pinelo et al., 2006; Bourvellec et al., 2009; Collinson dan Thielemans, 2010; Wang et al., 2015). Aktivitas antioksidan ekstrak senyawa fenolat beras ketan merah disajikan pada Gambar 2. Aktivitas antioksidan tertinggi yang ditunjukkan Gambar 2 merupakan ekstrak senyawa fenolat bebas, terkonjugasi, dan terikat terdapat pada ketan merah pecah kulit yaitu berturut-turut $\mathrm{IC}_{50}=4.52$; $\mathrm{IC}_{50}=32.92 ; \quad \mathrm{IC}_{50}=30.65 \mathrm{mg} / \mathrm{ml}$. Menurut Wang et al. (2015) sebanyak 74\% total fenolat yang terdapat pada varietas beras berwarna merupakan golongan fenolat yang tidak mudah larut dan dari segi aktivitas antioksidannya, senyawa fenolat terikat akan lebih tinggi dibandingkan senyawa fenolat bebas maupun terkonjugasi. Hasil pengujian aktivitas antioksidan yang tersaji pada Gambar 2 memiliki perbedaan dengan literatur yang justru menunjukkan ekstrak senyawa fenolat bebas memiliki aktivitas antioksidan lebih tinggi dibandingkan fenolat terkonjugasi dan fenolat terikat. Selain itu, pada pengujian total fenolat juga menunjukkan bahwa total fenolat senyawa fenolat terikat lebih tinggi dibandingkan dengan fenolat bebas. Hal ini disebabkan adanya perbedaan sampel ekstraksi yang digunakan dalam pengujian total fenolat dan aktivitas antioksidan. Pada pengujian aktivitas antioksidan, ekstrak sampel senyawa fenolat diperoleh dengan membuat ekstrak baru karena kadar ekstrak senyawa fenolat sebelumnya terlampau sedikit. Hal tersebut menyebabkan adanya kemungkinan perbedaan kandungan total fenolat pada ekstrak yang dapat terjadi karena beberapa faktor seperti kontak dengan oksigen yang lebih tinggi, paparan cahaya, suhu, dan $\mathrm{pH}$ yang berubah, sehingga dapat merusak komponen senyawa fenolat. Lemahnya korelasi antara kandungan total fenolat dan aktivitas antioksidan juga ditemukan pada penelitan sebelumnya (Heinonen et al., 1998; Tanunawong dan Tewaruth, 2010). Meskipun senyawa fenolat menunjukkan antioksidan terbesar pada suatu crude ekstrak, jenis antioksidan lainnya seperti karoten, tokoferol, dan lainnya, dimungkinkan hal tersebut dapat mempengaruhi keseluruhan aktivitas antioksidan yang teranalisis. Selain itu, aktivitas antioksidan tidak selalu tergantung pada jumlah dari total senyawa fenolat yang terukur, melainkan dari struktur senyawa fenolat (Tanunawong dan Tewaruth, 2010; Manquián-Cerda et al., 2016; Wu et al., 2016; Chiang et al., 2017). Gugus karbonil, asam aromatik, ester/lakton dapat meningkatkan aktivitas antioksidan. Selain itu, terlepasnya gugus karbonil dari cincin aromatik dan terdapatnya halangan sterik dapat meningkatkan aktivitas antioksidan pada sampel.

\section{SIMPULAN}

Kandungan senyawa fenolat dan aktivitas antioksidan telah diteliti pada bagian pecah kulit, ketan sosoh, dan bekatul beras ketan merah. Pada semua jenis sampel, baik pada ketan pecah kulit, ketan sosoh (bagian endosperm) maupun bekatul (bran) mengandung lebih banyak total fenolat terikat dan terkonjugasi daripada fenolat bebas. Aktivitas antioksidan ekstrak senyawa fenolat tertinggi terdapat pada ketan merah pecah kulit meliputi semua jenis fenolat yaitu ekstrak fenolat bebas $\mathrm{IC}_{50} 4.52 \mathrm{mg} / \mathrm{ml}$, fenolat terkonjugasi $3 \mathrm{IC}_{50} 9.92 \mathrm{mg} / \mathrm{ml}$, dan fenolat terikat $\mathrm{IC}_{50} 30.65 \mathrm{mg} / \mathrm{ml}$.

\section{DAFTAR PUSTAKA}

Alves, G, H, Ferreira, C, D, Vivian, P, G, Monks, J, L, F, Elias, M, C, Vanier, L, N, de Oliveira, M. 2016. The revisited levels of free and bound phenolics in rice: Effects of the extraction procedure. Food Chemistry. 208:116-123

Balai Besar Penelitian Tanaman Padi. 2015. Padi ketan: rendah kadar amilosa, tinggi kadar amilopektin. Dilihat 26 Oktober 2016. <http:/ / bbpadi.litbang. 
pertanian.go.id/index.php/berita/info-teknologi/content/183-padi-ketanrendah-kadar-amilosa-tinggi-kadaramilopektin>

Badan Perencanaan Pembangunan Daerah Pemerintah Provinsi Jawa Timur. 2015. Dokumentasi hasil pelaksanaan pembangunan kabupaten dan kota se-jawa timur tahun 2015. Dilihat 20 November 2016. <http:// bappeda.jatimprov.go.id/bappeda/wp-content/ uploads/2015/12/dokumentasi_kab_ kota_2015.pdf>

Bourvellec, C, L, Guyot, S, Renard, C, M, G, C. 2009. Interactions between apple (malus $x$ domestica Borkh.) polyphenols and cell walls modulate the extractability of polysaccharides. Carbohydrate Polymers. 75(22):251-261

Chen, G, L, Zhang, X, Chen, S, G, Han, M, D, Gao, Y, Q. 2017. Antioxidant activities and contents of free, esterified and insoluble-bound phenolics in 14 subtropical fruit leaves collected from the south of China. Journal of Functional Foods. 30:290-302

Chiang, P, S, Lee, D, J, Whiteley, C, G, Huang, C, Y. 2017. Antioxidant phenolic compounds from Pinus morrisconicola using compressional-puffing pretreatment and water-ethanol extraction: Optimization of extraction parameters. Journal of the Taiwan Institute of Chemical Engineers. 70:7-14

Collinson, S, R, Thielemans, W. 2010. The catalytic oxidation of biomass to new materials focusing on starch, cellulose and lignin. Coordination Chemistry Reviews. 254(15-16):1854-1870

Ernayanti. 2003. Ensiklopedi makanan tradisional di Pulau Jawa dan Pulau Madura. Kementerian Kebudayaan dan Pariwisata, Jakarta

Gunaratne, A, Wu, K, Li, D, Bentota, A, Corke, H, Cai, Y, Z. 2013. Antioxidant activity and nutritional quality of traditional red-grained rice varieties containing proanthocyanidins. Food Chemistry. 138(2-3):1153-1161

Heinonen, I, M, Meyer, A, S, Frankel, E, N. 1998. Antioxidant activity of berry phenolics on human low-density lipoprotein and liposome oxidation. J. Agric. Food Chem. 46(10):4107-4112

Kadirantau, DME. 2000. Kajian Isothermi Sorpsi Air (ISA) dan Stabilitas Tepung
Ketan selama Penyimpanan. Skripsi. IPB. Bogor

Kaliora, A, C, kogiannou, D, A, A, Kefalas, P, Papassideri, I, S, Kalogeropoulos, N. 2014. Phenolic profiles and antioxidant and anticarcinogenic activities of greek herbal infusions; balancing delight and chemoprevention?. Food Chemistry. 142:233-241

Li, L, Shewry, P, R, Ward, J, L. 2008. Phenolic acids in wheat varieties in the healthgrain diversity screen. J. Agric. Food Chem. 56(21): 9732-9739

Ling, W, H, Cheng, Q, X, Ma, J, Wang, T. 2001. Red and black rice decrease atheroscletoric plaque formation and increase antioxidant status in rabbits. J. Nutr. 131(5):1421-1426

Liu, R, H. 2007. Whole grain phytochemicals and health. Journal of Cereal Science. 46(3):207-219

Luo, C, Wang, X, Gao, G, Wang, L, Li, Y, Sun, C. 2013. Identification and quantification of free, conjugate and total phenolic compounds in leaves of 20 sweetpotato cultivars by HPLC-DAD and HPLC-ESI-MS/MS. Food Chemistry. 141(3):2697-2706

María, C, S, Revilla, E, Rodríguez-Morgado, B, Castaño, A, Carbonero, P, Gordillo, B, Cert, R, Parrado, J. 2016. Effect of rice parboiling on the functional properties of an enzymatic extract from rice bran. Journal of Cereal Science. 72:54-59

Manquián-Cerda, K, Escudey, M, Zúñiga, G, Arancibia-Miranda, N, Molina, M, Cruces, E. 2016. Effect of cadmium on phenolic compounds, antioxidant enzyme activity and oxidative stress in blueberry (Vaccinium corymbosum L.) plantlets grown in vitro. Ecotoxicology and Environmental Safety. 133:316-326

Muchlisyiyah, J, Prasmita, H, S, Estiasih, T, Laeliocattleya, R, A, Palupi, R. 2016. Sifat Fungsional tepung ketan merah pragelatinisasi. Jurnal Teknologi Pertanian. 17(3):195-202

Muntana, N, Prasong, S. 2010. Study on total phenolic contents and their antioxidant activities of thai white, red and black rice bran extracts. Pak. J. Biol. Sci. 13(4):170-174

Pinelo, M, Arnous, A, Meyer, A, S. 2006. Upgrading of grape skins: significance of plant cell-wall structural components and extraction techniques for phenol 
release. Trends in Food Science \& Technology. 17(11):579-590

Rasyid, HN. 2004. Ensiklopedi Makanan Tradisonal Indonesia (Sumatera). Kementerian Kebudayaan dan Pariwisata, Jakarta

Paiva, F, F, Vanier, N, L, de Jesus Berrios, J, Pan, J, de Almeida Villanova, F, Takeoka, G, Elias, M, C. 2014. Physicochemical and nutritional properties of pigmented rice subjected to different degrees of milling. Journal of Food Composition and Analysis. 35(1):10-17

Pereira-Caro, G, Watanabe, S, Crozier, A, Fujimura, T, Yokota, T, Ashihara, H. 2013. Phytochemical profile of a Japanese black-purple rice. Food Chemistry. 141(3):2821-2827

Qiu, Y, Liu, Q, Beta, T. 2010. Antioxidant properties of commercial wild rice and analysis of soluble and insoluble phenolic acids. Food Chemistry. 121(1):140-147

Rohaeni, W, R, Hastini, T. 2015. Inventarisasi padi lokal di kawasan ciater, subang, provinsi jawa barat. Pros. Sem. Nas. Masy. Biodiv. Indon. 1(2):189-193

Sattaka, P, Pattaratuma, S, Attawipakpaisan, G. 2017. Agricultural extension services to foster production sustainability for food and cultural security of glutinous rice farmers in Vietnam. Kasetsart Journal of Social Sciences. 38(1):74-80

Shao, Y, Bao, J. 2015. Polyphenols in whole rice grain: genetic diversity and health benefits. Food Chemistry. 180:86-97

Sharma, O, P, Bhat, T, J. 2009. DPPH antioxidant assay revisited. Food Chemistry. 113(4):1202-1205

Shen, Y, Jin, L, Xiao, P, Lu, Y, Bao, J. 2009. Total phenolics, flavonoids, antioxidant capacity in rice grain and their relations to grain color, size and weight. Journal of Cereal Science. 49(1):106-111

Sompong, R, Siebenhandl-Ehn, S, Linsberger-Martin, G, Berghofer, E. 2011. Physicochemical and antioxidative properties of red and black rice varieties from thailand, china and sri lanka. Food Chemistry. 124(1):132-140

Suhartatik, N, Cahyanto, M, N, Raharjo, S, Rahayu, E, S. 2013. Aktivitas antioksidan antosianin beras ketan hitam selama fermentasi. J. Teknol. dan Industri Pangan. 24(1):115-119

Suhartatik, N, Karyantina, M, Mustofa, A, Cahyanto, M, N, Raharjo, S, Rahayu, E, S. 2013. Stabilitas ektrak antosianin beras ketan (Oryza sativa var. glutinosa) hitam selama proses pemanasan dan penyimpanan. AGRITECH. 33(4):384390

Sukenti, K, Hakim, L, Indriyani, S, Purwanto, Y, Matthews, P, J. 2016. Ethnobotanical study on local cuisine of the sasak tribe in lombok island, indonesia. Journal of Ethnic Foods. 3(3):189-200

Tanunawong, K, Tewaruth, W. 2010. Extraction and application from black glutinous rice. LWT-Food Science and Technology. 43(3):476-481

Walter, M, Marchesan, E, Massoni, P, F, S, da Silva, L, P, Sartori, G, M, S, Ferreira, R, B. 2013. Antioxidant properties of rice grains with light brown, red and black pericarp colors and the effect of processing. Food Research International. 50(2):698-703

Wang, W, Guo, J, Zhang, J, Peng, J, Liu, T, Xin, Z. 2015. Isolation, identification and antioxidant activity of bound phenolic compounds present in rice bran. Food Chemistry. 171:40-49

Wu, X, Guan, W, Yan, R, Lei, J, Xu, L, Wang, Z. 2016. Effects of UV-C on antioxidant activity, total phenolics and main phenolic compounds of the melanin biosynthesis pathway in different tissues of button mushroom. Postharvest Biology and Technology. 118:51-58

Yawadio, R, Tanimori, S, Morita, N. 2007. Identification of phenolic compounds isolated from pigmented rices and their aldose reductase inhibitory activities. Food Chemistry. 101(4):1616-1625

Zhang, M, W, Zhang, R, F, Zhang, F, X, Liu, R, H. 2010. Phenolic profiles and antioxidant activity of black rice bran of different commercially available varieties. J. Agric. Food Chem. 58(13):75807587

Zaupa, M, Calani, L, Del Rio, D, Brighenti, F, Pellegrini, N. 2015. Characterization of total antioxidant capacity and (poly) phenolic compounds of differently pigmented rice varieties and their changes during domestic cooking. Food Chemistry. 187:338-347

Zhang, H, Shao, Y, Bao, J, Beta, T. 2015. Phenolic compounds and antioxidant properties of breeding lines between the white and black rice. Food Chemistry. 172:630-639 